\title{
Meridional distribution of aerosol optical thickness over the tropical Atlantic Ocean
}

\author{
P. Kishcha ${ }^{1}$, A. M. da Silva ${ }^{2}$, B. Starobinets ${ }^{1}$, C. N. Long ${ }^{3}$, O. Kalashnikova ${ }^{4}$, and \\ P. Alpert ${ }^{1}$ \\ ${ }^{1}$ Department of Geosciences, Tel-Aviv University, Tel-Aviv, Israel \\ ${ }^{2}$ Global Modeling and Assimilation Office, NASA/GSFC, Greenbelt, Maryland USA \\ ${ }^{3}$ Pacific Northwest National Laboratory, Richland, Washington, USA \\ ${ }^{4}$ Jet Propulsion Laboratory, California Institute of Technology, Pasadena, CA 91109, USA
}

Received: 9 July 2014 - Accepted: 24 August 2014 - Published: 10 September 2014

Correspondence to: P. Kishcha (pavelk@ post.tau.ac.il)

Published by Copernicus Publications on behalf of the European Geosciences Union.

\begin{abstract}
Previous studies showed that, over the global ocean, there is hemispheric asymmetry in aerosols and no noticeable asymmetry in cloud fraction (CF). In the current study, we focus on the tropical Atlantic $\left(30^{\circ} \mathrm{N}-30^{\circ} \mathrm{S}\right)$ which is characterized by significant 5 amounts of Saharan dust dominating other aerosol species over the North Atlantic. Over a limited area such as the tropical Atlantic, our study showed that strong meridional asymmetry in dust aerosols was accompanied by meridional CF asymmetry, by contrast to the global ocean. During the $10 \mathrm{yr}$ study period (July 2002-June 2012), NASA Aerosol Reanalysis (aka MERRAero) showed that, when the meridional asym10 metry in dust aerosol optical thickness (AOT) was the most pronounced (particularly in July), dust AOT averaged separately over the tropical North Atlantic was one order of magnitude higher than dust AOT averaged over the tropical South Atlantic. In the presence of such strong meridional asymmetry in dust AOT in July, CF averaged separately over the tropical North Atlantic exceeded CF averaged over the tropical South Atlantic

15 by $20 \%$. In July, along the Saharan Air Layer, Moderate Resolution Imaging Spectroradiometer (MODIS) CF data showed significant cloud cover (up to 0.8-0.9), which contributed to above-mentioned meridional CF asymmetry. Both Multi-Angle Imaging SpectroRadiometer (MISR) measurements and MERRAero data were in agreement on seasonal variations in meridional aerosol asymmetry. Meridional asymmetry in total AOT over the Atlantic was the most pronounced between March and July, when dust presence over the North Atlantic was maximal. In September and October, there was no noticeable meridional asymmetry in total AOT over the tropical Atlantic.
\end{abstract}

\section{Introduction}

Satellite observations have been widely used in the study of atmospheric turbidity and aerosol radiative properties because of their capability of providing global coverage on a regular basis. Previous studies, using different space-borne aerosol sensors, dis- 
cussed the idea that the hemispheres are asymmetric in aerosol distribution (Remer et al., 2008; Kaufman et al., 2005a; Remer and Kaufman, 2006; Mishchenko and Geogdzhayev, 2007; Chou et al., 2002; Zhang and Reid, 2010; Hsu et al., 2012; Kishcha et al., 2007, 2009). The Advanced Very High Resolution Radiometer (AVHRR) satellite 5 data over the ocean were used by Mishchenko and Geogdzhayev (2007) to compare monthly averaged aerosol optical thickness (AOT) over the Northern and Southern Hemispheres. They found a difference in AOT averaged over the two hemispheres. Chou et al. (2002) obtained meridional distribution of AOT over the ocean by using the Sea-viewing Wide Field-of-view Sensor (SeaWIFS) satellite data for the year 1998.

10 Hsu et al. (2012) displayed the asymmetric spatial distribution of seasonally-averaged SeaWiFS AOT from 1997 to 2010. Several studies based on the Moderate Resolution Imaging Spectroradiometer (MODIS) and Multi-Angle Imaging SpectroRadiometer (MISR) data showed that aerosol parameters are distributed asymmetrically on the two hemispheres (Remer et al., 2008; Kaufman et al., 2005a; Remer and Kaufman, 2006,

15 Zhang and Reid, 2010, Kishcha et al., 2007, 2009). In our previous study (Kishcha et al., 2009), AOT data from three satellite sensors (MISR, MODIS-Terra, and MODISAqua) were used in order to analyze seasonal variations of meridional AOT asymmetry over the global ocean. The asymmetry was pronounced in the April-July months, while there was no noticeable asymmetry during the season from September to December.

20 Kishcha et al. (2009) mentioned that not only the Northern Hemisphere but also the Southern Hemisphere contributed to the formation of noticeable meridional aerosol asymmetry. During the season of pronounced hemispheric aerosol asymmetry, an increase in AOT was observed over the Northern Hemisphere, while a decrease in AOT was observed over the Southern Hemisphere. It was found that, over the global ocean, 25 there was no noticeable asymmetry in meridional distribution of cloud fraction.

Note that the aforementioned studies of AOT asymmetry were based on spaceborne remote sensing aerosol measurements. Satellite aerosol data cannot usually distinguish among various aerosol species in the atmosphere. Although some satellite retrievals provide dust fraction of total AOT, there is a discrepancy between satellite

23311

datasets due to differences in their assumptions about aerosol and surface properties (Carboni et al., 2012). Consequently, the relative contribution of different aerosol species to hemispheric AOT asymmetry and their effects on meteorological parameters are not well understood.

The Sahara desert emits dust in large quantities over the tropical Atlantic (Prospero and Lamb, 2013). Previous studies have shown that desert dust particles can influence the Earth's atmosphere in the following ways: directly by scattering and absorbing solar and thermal radiation, and indirectly by acting as cloud and ice condensation nuclei (Choobari et al., 2013 and references therein, Pey et al., 2013). It was shown by

10 Wilcox et al. (2010) that the radiative effect of Saharan dust tends to draw the Atlantic Intertropical Convergence Zone (ITCZ) northward toward the Saharan Air Layer (SAL). Alpert et al. (1998) discussed the response of the atmospheric temperature field to the radiative forcing of Saharan dust over the North Atlantic Ocean. Dust particles over the Atlantic Ocean may essentially influence tropical cloud systems and precipitation

15 (Kaufman et al., 2005b; Min et al., 2009; Ben-Ami et al., 2009; Feingold et al., 2009; Rosenfeld et al., 2001).

To our knowledge, over a limited ocean area, meridional asymmetry of aerosols and cloud fraction relative to the equator has not been investigated so far. It was our purpose in the current study to compare meridional asymmetry of aerosols and cloud

20 fraction over the tropical Atlantic $\left(30^{\circ} \mathrm{N}-30^{\circ} \mathrm{S}\right)$ which is characterized by significant amounts of Saharan dust. We determined and compared the contribution of desert dust and that of other aerosol species to aerosol asymmetry between the tropical North and South Atlantic Oceans. Analyzing the meridional distribution of various aerosol species over the tropical Atlantic Ocean was carried out using the NASA Aerosol Re-

25 analysis (aka MERRAero). This reanalysis has been recently developed at NASA's Global Modeling Assimilation Office (GMAO) using a version of the NASA Goddard Earth Observing System-5 (GEOS-5) model radiatively coupled with Goddard Chemistry, Aerosol, Radiation, and Transport (GOCART) aerosols. An important property of GEOS-5 is data assimilation inclusion of bias-corrected aerosol optical thickness from 
the MODIS sensor on both Terra and Aqua satellites. Of course, AOT assimilation is effective only for two short periods of MODIS's appearance over the study area. All other time $\left(18 \mathrm{~h} \mathrm{day}^{-1}\right)$ the GEOS-5 model works independently of MODIS (Kishcha et al., 2014).

\section{GEOS-5 and the MERRA Aerosol Reanalysis (MERRAero)}

GEOS-5 is the latest version of the NASA Global Modeling and Assimilation Office (GMAO) Earth system model, which was used to extend the NASA Modern EraRetrospective Analysis for Research and Applications (MERRA) with five atmospheric aerosol components (sulfates, organic carbon, black carbon, desert dust, and sea-salt). GEOS-5 includes aerosols based on a version of the Goddard Chemistry, Aerosol Radiation, and Transport (GOCART) model (Colarco et al., 2010; Chin et al., 2002). Both dust and sea salt have wind-speed dependent emission functions (Colarco et al., 2010), while sulfate and carbonaceous species have emissions principally from fossil fuel combustion, biomass burning, and bio-fuel consumption, with additional biogenic 15 sources of organic carbon. Sulfate has additional chemical production from oxidation of $\mathrm{SO}_{2}$ and dimethylsulfide (DMS), as well as volcanic $\mathrm{SO}_{2}$ emissions. Aerosol emissions for sulfate and carbonaceous species are based on the AeroCom version 2 hindcast inventories (http://aerocom.met.no/emissions.html). Daily biomass burning emissions are from the Quick Fire Emission Dataset (QFED) and are derived from MODIS fire

20 radiative power retrievals (Darmenov and da Silva, 2013). GEOS-5 also includes assimilation of AOT observations from the MODIS sensor on both Terra and Aqua satellites. The obtained ten yr (July 2002-June 2012) MERRA-driven aerosol reanalysis (MERRAero) dataset was applied to the analysis of meridional aerosol asymmetry in the current study. In order to verify the obtained meridional aerosol distribution based 25 on MERRAero, we used the Multi-angle Imaging SpectroRadiometer (MISR) monthly global $0.5^{\circ} \times 0.5^{\circ}$ AOT dataset available over the study period.

23313

\section{Method}

Over the tropical Atlantic Ocean $\left(30^{\circ} \mathrm{N}-30^{\circ} \mathrm{S}\right)$, variations of zonal-averaged AOT as a function of latitude were used to analyze meridional aerosol distribution, following our previous study (Kishcha et al., 2009). This included total AOT and AOT of various aerosol species. To quantify meridional AOT asymmetry, the hemispheric ratio $(R)$ of AOT averaged separately over the tropical North Atlantic $\left(X_{N}\right)$ to that over the tropical South Atlantic $\left(X_{\mathrm{S}}\right)$ was estimated. The hemispheric ratio is equal to 1 in the case of the two parts of the tropical Atlantic holding approximately the same averaged AOT, while the ratio is greater (less) than 1 if the North (South) Atlantic dominates the other 10 one. Standard deviation of the reported hemispheric ratio (Table 1) was estimated in accordance with the following formula by Ku (1966), NIST/SEMATECH (2006):

$c_{R}=\frac{1}{\sqrt{N}} \cdot \frac{X_{\mathrm{N}}}{X_{\mathrm{S}}} \cdot \sqrt{\frac{c_{\mathrm{N}}^{2}}{X_{\mathrm{N}}^{2}}+\frac{C_{\mathrm{S}}^{2}}{X_{\mathrm{S}}^{2}}-2 \cdot \frac{c_{\mathrm{NS}}^{2}}{X_{\mathrm{N}} \cdot X_{\mathrm{S}}}}$

where $C_{\mathrm{N}}, C_{\mathrm{S}}$ are standard deviations of zonal averaged AOTs in the tropical North and South Atlantic Oceans respectively, $C_{\mathrm{NS}}$ is their covariance, and $N=120$ stands 15 for the number of months in the MISR/MERRAero AOT monthly data set used.

Variations of meridional aerosol distributions were analyzed by using MISR measurements and MERRAero data during the $10 \mathrm{yr}$ period, from July 2002 to June 2012 . The MISR swath width is about $380 \mathrm{~km}$ and global coverage is obtained every 9 days. MISR AOT has been extensively validated against Aerosol Robotic Network (AERONET) Sun

20 photometer measurements over different regions (Martonchik et al., 2004; Christopher and Wang, 2004; Kalashnikova and Kahn, 2008; Liu et al., 2004). For the purpose of comparing meridional distributions of cloud cover with those of AOT during the same $10 \mathrm{yr}$ period (July 2002-June 2012), Collection 5 of MODIS-Terra Level 3 monthly daytime cloud fraction (CF) data, with horizontal resolution $1^{\circ} \times 1^{\circ}$ was used 25 (King et al., 2003). Furthermore, to analyze meridional rainfall distribution, the Tropical 
Rainfall Measuring Mission (TRMM) monthly $0.25^{\circ} \times 0.25^{\circ}$ Rainfall Data Product (3B43 Version 7) was used (Huffman et al., 2007). MODIS CF data and TRMM data were acquired using the GES-DISC Interactive Online Visualization and Analysis Infrastructure (Giovanni) as part of NASA Goddard Earth Sciences (GES) Data and Information Services Center (DISC) (Acker and Leptoukh, 2007).

\section{Results}

\subsection{Ocean zone with the predominance of desert dust aerosols}

MERRAero showed that the Sahara desert emits a significant amount of dust into the atmosphere over the Atlantic Ocean (Fig. 1a, c, and e). With respect to different 10 oceans, MERRAero demonstrated that desert dust dominates all other aerosol species only over the Atlantic Ocean. Figure $1 b, d$, and $f$ represents spatial distribution of the ratio of dust AOT to AOT of all other aerosol species. The red contour lines represent the boundary of the zone where dust AOT is equal to AOT of all other aerosol species. One can see that, through the $10 \mathrm{yr}$ period under consideration, over the Atlantic Ocean within the latitudinal zone between 7 and $30^{\circ} \mathrm{N}$, Saharan dust dominates other aerosol species (Fig. 1b). The longitudinal dimension of this zone is subject to seasonal variability. During the dusty season from March to July, the zone of dust predominance occupies a significant part of the tropical Atlantic between North Africa and Central America. Specifically, as shown in Fig. 1d, in July, the zone of dust predominance is extremely extensive. By contrast, from October to February, this zone is observed only over some limited territory close to North Africa.

Desert dust can be seen not only over the Atlantic Ocean, but also over the Pacific and Indian Oceans (Fig. 1a, C, and e). However, outside the Atlantic Ocean, one can see only limited zones of desert dust predominance over the Mediterranean Sea and 25 over the Arabian Sea (Fig. 1b, d, and f). Therefore, the tropical North Atlantic Ocean

23315

is the largest ocean area where dust particles determine the atmospheric aerosol content, based on MERRAero data.

\subsection{Meridional distribution of total AOT over the tropical Atlantic Ocean}

Figure 2a represents meridional distribution of tenyr mean AOT (July 2002-June 5 2012), zonal averaged over the tropical Atlantic Ocean. One can see that MERRAero showed similarity to the meridional AOT distribution, based on MISR data (Fig. 2a). Specifically, MERRAero was able to reproduce the meridional asymmetry in the AOT distribution, including a monomodal maximum in the tropical North Atlantic and a minimum in the tropical South Atlantic. This monomodal AOT maximum was discussed in

our previous study (Kishcha et al., 2009). Both MISR and MERRAero showed that, in the minimum, the AOT values were three times lower than those in the maximum. We quantified meridional AOT asymmetry in the tropical Atlantic Ocean $\left(30^{\circ} \mathrm{N}-30^{\circ} \mathrm{S}\right)$ by obtaining the hemispheric ratio $\left(R_{\mathrm{AOT}}\right)$ of $\mathrm{AOT}$ averaged separately over the tropical North Atlantic to AOT averaged over the tropical South Atlantic: $R_{\mathrm{AOT}}$ was estimated 15 to be about 1.7 (Table 1). This means that, over the $10 \mathrm{yr}$ period under consideration, there were much more aerosol particles over the tropical North Atlantic than over the tropical South Atlantic.

\subsection{Seasonal variations of meridional distribution of AOT}

For each month of the year, we analyzed variations of meridional distribution of AOT ${ }_{20}$ over the tropical Atlantic Ocean (Fig. 3). It was found that the meridional AOT distribution is seasonal dependent. In particular, both MISR and MERRAero were in agreement that the monomodal AOT maximum, a characteristic feature of meridional asymmetry in AOT, exists but not in each month. In the months from September to October, two AOT maxima can be observed: one maximum in the North Atlantic, and another one in the South Atlantic. 
Figure 4 represents month-to-month variations of the hemispheric ratio $R_{\mathrm{AOT}}$ over the tropical Atlantic for each month of the year. Both MISR and MERRAero showed that meridional AOT asymmetry was most pronounced during the season from March to July. One can see that, from month to month during the year, $R_{\mathrm{AOT}}$ ranges from 1-2.4, 5 while during the season of pronounced meridional aerosol asymmetry (March-July) $R_{\mathrm{AOT}}$ ranges from 2.0-2.4. In September and October, $R_{\mathrm{AOT}}$ was close to 1 , indicating no noticeable asymmetry (Fig. 4).

\subsection{Meridional distribution of AOT of various aerosol species}

Figure 2c represents meridional distribution of ten-year mean MERRAero AOT for to10 tal AOT (Total), dust AOT (DU), organic and black carbon aerosol AOT (OC and BC), and AOT of other aerosol species (Other), zonal averaged over the tropical Atlantic Ocean. One can see that meridional dust distribution is much more asymmetric relative to the equator than meridional distribution of $\mathrm{OC}$ and $\mathrm{BC}$ and other aerosol species. The meridional asymmetry of $\mathrm{DU}$, characterized by the hemispheric ratio $\left(R_{\mathrm{DU}}\right)$ of

15 dust AOT was about 11 (Table 2). Such strong asymmetry in meridional distribution of desert dust over the ocean can be explained by its transport by winds from the Sahara desert to the ocean in the North Atlantic. Being the major contributor to the AOT maximum in the North Atlantic, Saharan dust was responsible for the pronounced meridional AOT asymmetry in total AOT over the tropical Atlantic Ocean. Carbon aerosols also displayed some meridional asymmetry characterized by the hemispheric ratio $R_{\mathrm{OC}}$ and $\mathrm{BC}=0.7$, although this asymmetry was much less pronounced than that of desert dust (Fig. 2c and Table 2). Meridional distribution of AOT of other aerosol species was almost symmetrical $\left(R_{\text {Other }}\right.$ is 1.1$)$ (Table 2). Therefore, aerosols over the tropical Atlantic can be divided into two groups with different meridional distribution rel-

25 ative to the equator: dust and carbonaceous aerosols were distributed asymmetrically, while other aerosol species were distributed almost symmetrically.

MERRAero showed that seasonal variations of transatlantic Saharan dust transport determined the seasonal variations of meridional dust asymmetry. In May-July, when 23317

meridional asymmetry in dust AOT over the tropical North Atlantic was the most pronounced, dust AOT averaged separately over the tropical North Atlantic was one order of magnitude higher than dust AOT averaged over the tropical South Atlantic (Table 2). In July, the most pronounced meridional asymmetry of dust AOT was characterized by 5 the hemispheric ratio $R_{\mathrm{DU}}$ of about 30 (Table 2).

When dust presence over the North Atlantic was minimal, the contribution of other aerosol species to the meridional distribution of total AOT could be significant. In particular, in December, the maximum in $\mathrm{OC}$ and $\mathrm{BC}$ at low-latitudes (due to the transport of bio-mass burning smoke) contributed significantly to the maximum in total AOT in 10 the tropical North Atlantic (Fig. 5a). Note that the reason for the aforementioned transport of bio-mass burning aerosols is the burning of agricultural waste in the Sahelian region of northern Africa. This burning activity is maximal during December-February (Haywood et al., 2008). MERRAero showed that no noticeable meridional asymmetry of total AOT was observed in September and October (Fig. 4). This is because the con-

15 tribution of carbonaceous aerosols (OC and BC) to total AOT over the South Atlantic is comparable to the contribution of Saharan dust to total AOT in the North Atlantic (Fig. 5). The reason for the observed increase in OC and BC over the South Atlantic in September and October is that these months fall within the burning period in Central Africa, where slash-and-burn agriculture is prevalent (Tereszchuk et al., 2011). In

20 September and October, AOT of carbonaceous aerosols over the tropical South Atlantic was five times higher than that over the tropical North Atlantic $\left(R_{\mathrm{OC}}\right.$ and $\left.\mathrm{BC}=0.2\right)$ (Table 2).

Meridional distribution of AOT of other aerosol species remains more symmetrical than dust and carbonaceous aerosols throughout all months (the hemispheric ratio

${ }_{25} R_{\text {Other }}$ ranged from 0.8-1.3) (Table 2). This group includes marine aerosols, such as sea-salt and dimethylsulfide (DMS) aerosols, which are produced everywhere in the tropical Atlantic Ocean. 


\subsection{Meridional distribution of cloud fraction}

We analyzed meridional distribution of cloud cover over the tropical $\left(30^{\circ} \mathrm{N}-30^{\circ} \mathrm{S}\right)$ Atlantic Ocean, which includes the area of transatlantic Saharan dust transport within $\mathrm{SAL}$. Figure $2 \mathrm{~b}$ represents the meridional distribution of $10 \mathrm{yr}$ mean cloud fraction, 5 zonal averaged over the Atlantic Ocean. One can see the local maximum near the equator due to clouds concentrated over the Intertropical Convergence Zone: this maximum shifts to the north from the equator. Despite this CF maximum, the hemispheric CF ratio $\left(R_{\mathrm{CF}}\right)$, characterized by the ratio of CF averaged separately over the tropical North and over the South Atlantic, did not exceed 1.1 (Table 1).

10 As mentioned in Sect. 4.4, MERRAero showed that dust and carbonaceous aerosols were distributed asymmetrically in relation to the equator, while other aerosol species were distributed almost symmetrically. During the period of pronounced meridional AOT asymmetry over the tropical Atlantic from May-July, dust AOT averaged separately over the tropical North Atlantic was about one order of magnitude higher than

15 dust AOT averaged over the tropical South Atlantic (Table 2). In July, the hemispheric ratio $R_{\mathrm{DU}}$ was roughly 30 . In the presence of such strong meridional dust asymmetry, in July, $R_{\mathrm{CF}}$ reached 1.2 (Table 2). As shown in previous study (Kishcha et al., 2009), over the global ocean, $R_{\mathrm{AOT}}$ was about 1.5 , while $R_{\mathrm{CF}}$ was 1 . Therefore, by contrast to the global ocean (where meridional CF distribution was symmetrical over the two

20 hemispheres), over the tropical Atlantic in July, CF averaged separately over the tropical North Atlantic exceeded CF averaged over the tropical South Atlantic by $20 \%$. In September-October, when there was no meridional asymmetry in total AOT over the tropical Atlantic $\left(R_{\mathrm{AOT}}\right.$ was close to 1$)$, meridional CF distribution was almost symmetrical $\left(R_{\mathrm{CF}}\right.$ was close to 1 , Table 2$)$.

25 Figure 6 represents meridional distribution of MODIS CF and TRMM accumulated rainfall, zonal averaged over the tropical Atlantic Ocean, for all months of the year. One can see some changes in CF from month to month on the high background level of

23319

approximately 0.6. This background level of CF is almost the same over the tropical North and South Atlantic Oceans.

In each month, the main CF maximum coincides with the Atlantic Ocean inter-tropical convergence zone, which is characterized by intensive rainfall (Fig. 6). In the summer 5 months (when pronounced meridional dust asymmetry was observed), MODIS CF data showed significant CF to the north from the main CF maximum, over the latitudes of transatlantic dust transport within the Saharan Air Layer (SAL) (Fig. 6g-i). Saharan dust travels across the Atlantic Ocean within the hot and dry Saharan Air Layer (Dunion and Velden, 2004). The SAL's base is at $~ 900-1800 \mathrm{~m}$ and the top is usually below $5500 \mathrm{~m}$

10 (Diaz et al., 1976). The significant cloud fraction along SAL, together with the Atlantic Inter-tropical Convergence Zone (centered over the tropical North Atlantic) contributed to the above-mentioned meridional CF asymmetry. Following is our analysis of cloud fraction in the area of the Saharan Air Layer in July, when the most pronounced meridional dust asymmetry was observed.

\section{${ }_{15}$ 4.5.1 Cloud fraction in the area of the Saharan Air Layer in July}

Figure 7 represents meridional distribution of the $10 \mathrm{yr}$ mean of MERRAero dust AOT, MODIS-Terra cloud fraction, and TRMM accumulated rainfall, zonal averaged over the Atlantic Ocean $\left(60^{\circ} \mathrm{W}-0^{\circ} \mathrm{E}\right)$. The near-equatorial maximum in meridional distribution of TRMM accumulated rainfall indicates the position of the North Atlantic Ocean inter-

20 tropical convergence zone (ITCZ) (Fig. 7). One can see that, in July, when dust presence over the Atlantic is maximal, the meridional distribution of CF becomes essentially asymmetric with respect to the center of ITCZ. In particular, significant CF up to 0.8 is seen northward from ITCZ, over the latitudes with SAL presence $\left(12-24^{\circ} \mathrm{N}\right.$ ) (Fig. 7). These values are higher than the $10 \mathrm{yr}$ mean MODIS CF over the tropical North Atlantic

25 (0.66) (Table 1). One can consider that, in the North Atlantic, the wide maximum in the meridional distribution of CF consists of two different partly-overlapping maxima: one CF maximum located within ITCZ, and the other CF maximum located over the ocean area where Saharan dust is transported within the SAL across the Atlantic (Fig. 7). 
More detailed information about the aforementioned two partly-overlapping maxima in the meridional distribution of CF in July can be obtained from a comparison between spatial distribution of ten yr mean MERRAero dust AOT and MODIS CF over the tropical North Atlantic (Fig. 8a and b). It is clearly seen that the ocean area with Saharan dust

5 transported across the Atlantic is covered by cloudiness characterized by significant values of MODIS CF up to $0.8-0.9$. This CF is higher than the $10 \mathrm{yr}$ mean MODIS CF over the tropical North Atlantic (0.66) (Table 1). Note that there is a strong difference between the two zones of significant CF in the North Atlantic. High values of CF within ITCZ are accompanied by intensive rainfall (Fig. 8b and c). By contrast, the area of

10 SAL with significant $\mathrm{CF}\left(12^{\circ} \mathrm{N}-24^{\circ} \mathrm{N}\right)$ is characterized by essentially lower precipitation (Fig. 8b and c).

We analyzed the $10 \mathrm{yr}$ mean (July 2002-June 2012) of dust and cloudiness over six zones, each $6^{\circ} \times 6^{\circ}$, located along the area of transatlantic dust transport (Fig. 8a). In July, there was a decline of approximately $300 \%$ in dust AOT from zone 1 to zone 6

15 (Fig. 9a). The reason for the decline in dust AOT with increasing distance from dust sources in the Sahara is gravitational settling of dust particles (mainly coarse fraction). Zone-to-zone variations of MODIS CF were considerably less pronounced: CF over zones 1 and 2 ranged from $0.8-0.9$, while CF over zones from 3 to 6 was about 0.7 (Fig. 9b). Zone-to-zone variations of $10 \mathrm{yr}$ mean TRMM accumulated rainfall revealed

20 a significant increase over zones remote from the Sahara: there were higher values $(70-110 \mathrm{~mm})$ over zones 5 and 6 than over zones 1-4 $(20-30 \mathrm{~mm})$ (Fig. 9b). This increase in rainfall over zones 5 and 6 indicated an increase in the precipitation ability of clouds over these zones.

Temperature inversion at the base of the Saharan Air Layer prevents deep cloud de25 velopment and precipitation (Prospero and Carlson, 1972). We analyzed temperature inversion over zones 1-6. Figure 10 represents vertical profiles of atmospheric temperature averaged over the specified zones, in July during the $10 \mathrm{yr}$ period under consideration. The observed temperature inversion over zones 1-4 (Fig. 10) prevented convective activity and precipitation, which explains the observed low accumulated rainfall

$$
23321
$$

(Fig. 9b). There was no temperature inversion over zones 5 and 6 (Fig. 10). In the absence of temperature inversion there is no suppression of deep cloud formation and precipitation. This explains the increase in TRMM accumulated rainfall over zones 5 and 6.

\section{Conclusions}

Meridional distribution of aerosol optical thickness and cloud fraction were analyzed using $10 \mathrm{yr}$ satellite measurements from MISR and MODIS, together with MERRAero data (July 2002-June 2012).

In accordance with our previous study (Kishcha et al., 2009), over the global ocean,

10 there is hemispheric asymmetry in aerosols and no noticeable asymmetry in cloud fraction. In the current study, we focus on the tropical Atlantic $\left(30^{\circ} \mathrm{N}-30^{\circ} \mathrm{S}\right)$ which is characterized by significant amounts of Saharan dust. Over a limited area such as the tropical Atlantic, we found that strong meridional asymmetry in dust aerosols was accompanied by meridional CF asymmetry, by contrast to the global ocean.

15 When meridional AOT asymmetry over the tropical North Atlantic was the most pronounced, dust AOT averaged separately over the tropical North Atlantic was one order of magnitude higher than dust AOT averaged over the tropical South Atlantic. In July, the most pronounced meridional asymmetry of dust AOT was characterized by the hemispheric ratio $R_{\mathrm{DU}}$ of approximately 30 . In the presence of such strong merid20 ional asymmetry in dust AOT in the summer months, CF averaged separately over the tropical North Atlantic exceeded CF averaged over the tropical South Atlantic by $20 \%$. In July, along the Saharan Air Layer, MODIS CF data showed significant cloud cover (up to 0.8-0.9) with limited precipitation ability (TRMM accumulated rainfall 20$30 \mathrm{~mm} \mathrm{month}^{-1}$ ). These CF values are higher than the $10 \mathrm{yr}$ mean MODIS CF over

25 the tropical North Atlantic (0.66) (Table 1). This significant cloud fraction along SAL together with the Atlantic Inter-tropical Convergence Zone (centered over the tropical 
North Atlantic and characterized by significant cloud cover) contribute to the abovementioned meridional CF asymmetry.

With respect to different oceans, only over the Atlantic Ocean did MERRAero demonstrate that desert dust dominated all other aerosol species and was responsible for 5 meridional aerosol asymmetry there. MERRAero showed that, over the tropical Atlantic, dust and carbonaceous aerosols were distributed asymmetrically relative to the equator, while other aerosol species were distributed more symmetrically.

Both MISR measurements and MERRAero data were in agreement on seasonal variations in meridional aerosol asymmetry. Meridional asymmetry in total AOT over the

10 Atlantic was the most pronounced between March and July, when dust presence over the North Atlantic was maximal. In September and October, there was no noticeable meridional aerosol asymmetry in total AOT $\left(R_{\mathrm{AOT}}\right.$ was close to 1$)$. During these two months, the contribution of carbonaceous aerosols to total AOT in the South Atlantic was comparable to the contribution of dust aerosols to total AOT in the North Atlantic.

15 Our study showed that, in September and October, meridional CF distribution over the tropical Atlantic was almost symmetrical $\left(R_{\mathrm{CF}}\right.$ was close to 1$)$.

Acknowledgements. We acknowledge the GES-DISC Interactive Online Visualization and Analysis Infrastructure (Giovanni) for providing us with MODIS CF and TRMM data. Dr. Long acknowledges support from the Office of Biological and Environmental Research of the US

20 Department of Energy as part of the Atmospheric Systems Research Program. The Tel-Aviv University team acknowledges support from the international Virtual Institute DESERVE (Dead Sea Research Venue), funded by the German Helmholtz Association.

\section{References}

Acker, J. G. and Leptoukh, G.: Online analysis enhances use of NASA Earth science data, EOS T. Am. Geophys. Un., 88, 14-17, doi:10.1029/2007EO020003, 2007.

Alpert, P., Kaufman, Y. J., Shay-EI, Y., Tanre, D., da Silva, A., Schubert, S., and Joseph, J. H.: Quantification of dust-forced heating of the lower troposphere, Nature, 395, 367-370, 1998.

23323

Ben-Ami, Y., Koren, I., and Altaratz, O.: Patterns of North African dust transport over the Atlantic: winter vs. summer, based on CALIPSO first year data, Atmos. Chem. Phys., 9, 78677875, doi:10.5194/acp-9-7867-2009, 2009.

Carboni, E., Thomas, G. E., Sayer, A. M., Siddans, R., Poulsen, C. A., Grainger, R. G., Ahn, C., Antoine, D., Bevan, S., Braak, R., Brindley, H., DeSouza-Machado, S., Deuzé, J. L., Diner, D., Ducos, F., Grey, W., Hsu, C., Kalashnikova, O. V., Kahn, R., North, P. R. J., Salustro, C., Smith, A., Tanré, D., Torres, O., and Veihelmann, B.: Intercomparison of desert dust optical depth from satellite measurements, Atmos. Meas. Tech., 5, 1973-2002, doi:10.5194/amt-51973-2012, 2012.

10 Chin, M., Ginoux, P., Kinne, S., Torres, O., Holben, B., Duncan, B. N., Martin, R. V., Logan, J., Higurashi, A., and Nakajima, T.: Tropospheric aerosol optical thickness from the GOCART model and comparisons with satellite and sun photometer measurements, J. Atmos. Phys., 59, 461-483, doi:10.1175/1520-0469(2002)059<0461:TAOTFT>2.0.CO;2, 2002.

Colarco, P., da Silva, A., Chin, M., and Diehl, T.: Online simulations of global aerosol distributions in the NASA GEOS-4 model and comparisons to datellite and ground-based aerosol optical depth, J. Geophys. Res., 115, D14207, doi:10.1029/2009JD012820, 2010.

Choobari, O. A., Zawar-Reza, P., and Sturman, A.: The global distribution of mineral dust and its impacts on the climate system: a review, Atmos. Res., 138, 152-165, doi:10.1016/j.atmosres.2013.11.007, 2014.

20 Chou, M.-D., Chan, P.-K., and Wang, M.: Aerosol radiative forcing derived from SeaWIFSRetrieved aerosol optical properties, J. Atmos. Sci. (Global Aerosol Climatology special issue), 59, 748-757, 2002.

Christopher, S. and Wang, J.: Intercomparison between multi-angle Imaging SpectroRadiometer (MISR) and sunphotometer aerosol optical thickness in dust source regions of China,

25 implications for satellite aerosol retrievals and radiative forcing calculations, Tellus B, 56, 451-456, 2004.

Darmenov, A. and da Silva, A.: The Quick Fire Emissions Dataset (QFED) - Documentation of Versions 2.1, 2.2 and 2.4, NASA Technical Report Series on Global Modeling and Data Assimilation, NASA TM-2013-104606, 32, 183 pp., NASA, Greenbelt, MD, 2013.

30 Diaz, H. F., Carlson, T. N., and Prospero, J. M.: A Study of the Structure and Dynamics of the Saharan Air Layer Over the Northern Equatorial Atlantic During BOMEX, NOAA Tech Memo ERL WMPO-32, NOAA, Silver Spring, Md., 61 pp., 1976. 
Dunion, J. P. and Velden, C. S.: The impact of the Saharan air layer on Atlantic tropical cyclone activity, B. Am. Meteorol. Soc., 85, 353-365, doi:10.1175/BAMS-85-3-353, 2004.

Feingold, G., Cotton, W., Lohmann, U., and Levin, Z.: Effects of pollution aerosols and biomass burning on clouds and precipitation: numerical modeling studies, in: Aerosol Pollution Impact on Precipitation, edited by: Leven, Z. and Cotton, W., Springer, , chapt. 7, 243-278, 2009.

Haywood, J. M., Pelon, J., Formenti, P., Bharmal, N., Brooks, M., Capes, G., Chazette, P., Chou, C., Christopher, S., Coe, H., Cuesta, J., Derimian, Y., Desboeufs, K., Greed, G., Harrison, M., Heese, B., Highwood, E. J., B. Johnson, B., Mallet, M., Marticorena, B., Marsham, J., Milton, S., Myhre, G., Osborne, S. R., Parker, D. J., Rajot, J.-L., Schulz, M., Slingo, A., Tanre,

10 D., P., and Tulet, P.: Overview of the Dust and Biomass-burning Experiment and African Monsoon Multidisciplinary Analysis Special Observing Period-0. J. Geophys. Res., 113, D00C17, doi:10.1029/2008JD010077, 2008.

Hsu, N. C., Gautam, R., Sayer, A. M., Bettenhausen, C., Li, C., Jeong, M. J., Tsay, S. C., and Holben, B.: Global and regional trends of aerosol optical depth over land and ocean

15 using SeaWiFS measurements from 1997 to 2010. Atmos. Chem. Phys., 12, 8037-8053, doi:10.5194/acp-12-8037-2012, 2012.

Huffman, G. J., Adler, R. F., Bolvin, D. T., Gu, G., Nelkin, E. J., Bowman, K. P., Hong, Y., Stocker, E. F., Wolff, D. B.: The TRMM multisatellite precipitation analysis (TMPA): quasiglobal, multiyear, combined-sensor precipitation estimates at fine scales, J. Hydrometeorol.,

$20 \quad$ 8, 38-55, doi:10.1175/JHM560.1, 2007.

Kalashnikova, O. V. and Kahn, R.: Mineral dust plume evolution over the Atlantic from MISR and MODIS aerosol retrievals, J. Geophys. Res., 113, D24204, doi:10.1029/2008JD010083, 2008.

Kaufman, Y. J., Boucher, O., Tanre, D., Chin, M., Remer, L. A., and Takemura, T.: Aerosol anthropogenic component estimated from satellite data, Geophys. Res. Lett., 32, L17804, doi:10.1029/2005GL023125, 2005a.

Kaufman, Y. J., Koren, I., Remer, L., Rosenfeld, D., and Rudich, Y.: The effect of smoke, dust, and pollution aerosol on shallow cloud development over the Atlantic Ocean, P. Natl. Acad. Sci. USA, 102, 11207-11212, 2005b.

30 King, M. D., Menzel, W. P., Kaufman, Y. J., Tanre, D., Gao, B. C., Platnick, S., Ackerman, S. A., Remer, L. A., Pincus, R. and Hubanks, P. A.: Cloud and aerosol properties, precipitable water, and profiles of temperature and humidity from MODIS, IEEE T. Geosci. Remote, 41, 442-458, 2003.

$$
23325
$$

Kishcha, P., Starobinets, B., and Alpert, P.: Latitudinal variations of cloud and aerosol optical thickness trends based on MODIS satellite data, Geophys. Res. Lett., 34, L05810, doi:10.1029/2006GL028796, 2007.

Kishcha, P., Starobinets, B., Kalashnikova, O., Long, C. N., and Alpert, P.: Variations in meridional aerosol distribution and solar dimming, J. Geophys. Res., 114, D00D14, doi:10.1029/2008JD010975, 2009.

Kishcha, P., da Silva, A. M., Starobinets, B., and Alpert, P.: Air pollution over the Ganges basin and north-west Bay of Bengal in the early post-monsoon season based on NASA MERRAero data, J. Geophys. Res.-Atmos., 119, 1555-1570, doi:10.1002/2013JD020328, 2014.

$10 \mathrm{Ku}, \mathrm{H}$. : Notes on the use of propagation of error formulas, J. Res. Nbs. C Eng. Inst., 70, 263273, 1966.

Liu, Y., Sarnat, J. A., Coull, B. A., Koutrakis, P. and Jacob, D. J.: Validation of Multiangle Imaging Spectroradiometer (MISR) aerosol optical thickness measurements using Aerosol Robotic Network (AERONET) observations over the contiguous United States, J. Geophys. Res., 109, D06205, doi:10.1029/2003JD003981, 2004.

Min, Q.-L., Li, R., Lin, B., Joseph, E., Wang, S., Hu, Y., Morris, V., and Chang, F.: Evidence of mineral dust altering cloud microphysics and precipitation, Atmos. Chem. Phys., 9, 32233231, doi:10.5194/acp-9-3223-2009, 2009.

Matronchik, J. V., Diner, D. J., Kahn, R., and Gaitley, B.: Comparison of MISR and AERONET aerosol optical depths over desert sites, Geophys. Res. Lett., 31, L16102, doi:10.1029/2004GL019807, 2004.

Mishchenko, M. I. and Geogdzhayev, I. V.: Satellite remote sensing reveals regional tropospheric aerosol trends, Opt. Express, 15, 7423-7438, doi:10.1364/OE.15.007423, 2007.

NIST/SEMATECH e-Handbook of Statistical Methods: available at: http://www.itl.nist.gov/ div898/handbook/ (last access: 07 September 2014), 2006.

Pey, J., Querol, X., Alastuey, A., Forastiere, F., and Stafoggia, M.: African dust outbreaks over the Mediterranean Basin during 2001-2011: $\mathrm{PM}_{10}$ concentrations, phenomenology and trends, and its relation with synoptic and mesoscale meteorology, Atmos. Chem. Phys., 13, 1395-1410, doi:10.5194/acp-13-1395-2013, 2013.

30 Prospero, J. and Carlson, T.: Vertical and areal distribution of Saharan dust over the Western Equatorial North Atlantic Ocean, J. Geophys. Res., 77, 5255-5265, doi:10.1029/JC077i027p05255, 1972. 
Prospero, J. and Lamb, J.: African droughts and dust transport to the Caribian: climate change and implications, Science, 302, 1024-1027, doi:10.1126/science.1089915, 2003.

Remer, L. A. and Kaufman, Y. J.: Aerosol direct radiative effect at the top of the atmosphere over cloud free ocean derived from four years of MODIS data, Atmos. Chem. Phys., 6, 237-253, doi:10.5194/acp-6-237-2006, 2006.

Remer, L. A., Kleidman, R. G., Levy, R. C., Kaufman, Y. J., Tanre, D., Mattoo, S., Martins, J. V., Ichoku, C., Koren, I., Hongbin, Yu, Holben, B. N.: Global aerosol climatology from the MODIS satellite sensors, J. Geophys. Res., 113, D14S07, doi:10.1029/2007JD009661, 2008.

Rosenfeld, D., Rudich, Y., Lahav, R.: Desert dust suppressing precipitation - a possible desertification feedback loop, P. Natl. Acad. Sci. USA, 98, 5975-5980, 2001.

Tereszchuk, K. A., González Abad, G., Clerbaux, C., Hurtmans, D., Coheur, P.-F., and Bernath, P. F.: ACE-FTS measurements of trace species in the characterization of biomass burning plumes, Atmos. Chem. Phys., 11, 12169-12179, doi:10.5194/acp-11-12169-2011, 2011.

15 Wilcox, E. M., Lau, K. M., and Kim, K. M.: A northward shift of the North Atlantic Ocean Intertropical Convergence Zone in response to summertime Saharan dust outbreaks, Geophys. Res. Lett., 37, L04804, doi:10.1029/2009GL041774, 2010.

Zhang, J. and Reid, J. S.: A decadal regional and global trend analysis of the aerosol optical depth using a data-assimilation grade over-water MODIS and Level 2 MISR aerosol products, Atmos. Chem. Phys., 10, 10949-10963, doi:10.5194/acp-10-10949-2010, 2010.

Table 1. Average AOT and CF over the tropical North $\left(X_{\mathrm{N}}\right)$ and South $\left(X_{\mathrm{S}}\right)$ Atlantic and their hemispheric ratio $(R)^{*} .10 \mathrm{yr}$ MERRAero AOT, MISR AOT, and MODIS CF data were used.

\begin{tabular}{llll}
\hline Data set & $X_{\mathrm{N}} \pm \sigma_{\mathrm{N}}$ & $X_{\mathrm{S}} \pm \sigma_{\mathrm{S}}$ & $R \pm \sigma_{R}$ \\
\hline MISR AOT & $0.25 \pm 0.06$ & $0.15 \pm 0.05$ & $1.70 \pm 0.06$ \\
MERRAero AOT & $0.19 \pm 0.05$ & $0.12 \pm 0.05$ & $1.61 \pm 0.06$ \\
MODIS CF & $0.66 \pm 0.09$ & $0.61 \pm 0.06$ & $1.08 \pm 0.01$
\end{tabular}

${ }^{*}$ Standard deviations of $X_{\mathrm{N}}, X_{\mathrm{S}}$, and $R$ are designated by $\sigma_{\mathrm{N}}, \sigma_{\mathrm{S}}, \sigma_{R}$ respectively. 
Table 2. The hemispheric ratio ( \pm standard deviation) of dust AOT (DU), organic and black carbon AOT (OC and BC), other aerosol species AOT (Other), and MODIS CF over the tropical Atlantic Ocean $\left(30^{\circ} \mathrm{N}-30^{\circ} \mathrm{S}\right) .10 \mathrm{yr}$ MERRAero data and MODIS CF data were used.

\begin{tabular}{lcccc}
\hline Month & DU & OC and BC & Other & MODIS CF \\
\hline All months & $11.50 \pm 1.20$ & $0.70 \pm 0.10$ & $1.10 \pm 0.10$ & $1.08 \pm 0.01$ \\
Jan & $6.10 \pm 2.30$ & $1.30 \pm 0.50$ & $1.10 \pm 0.10$ & $1.10 \pm 0.07$ \\
Feb & $4.20 \pm 1.80$ & $1.20 \pm 0.40$ & $1.20 \pm 0.10$ & $1.15 \pm 0.09$ \\
Mar & $6.90 \pm 3.20$ & $2.00 \pm 0.40$ & $1.20 \pm 0.10$ & $1.14 \pm 0.10$ \\
Apr & $8.80 \pm 4.10$ & $2.70 \pm 0.40$ & $1.20 \pm 0.10$ & $1.07 \pm 0.09$ \\
May & $21.00 \pm 10.10$ & $1.70 \pm 0.30$ & $1.20 \pm 0.10$ & $1.14 \pm 0.07$ \\
Jun & $23.50 \pm 10.80$ & $0.90 \pm 0.30$ & $1.30 \pm 0.10$ & $1.20 \pm 0.09$ \\
Jul & $29.30 \pm 10.30$ & $0.70 \pm 0.30$ & $1.30 \pm 0.20$ & $1.21 \pm 0.08$ \\
Aug & $25.00 \pm 8.50$ & $0.40 \pm 0.10$ & $1.10 \pm 0.10$ & $1.04 \pm 0.07$ \\
Sep & $23.80 \pm 6.70$ & $0.20 \pm 0.10$ & $0.90 \pm 0.10$ & $0.98 \pm 0.05$ \\
Oct & $17.00 \pm 4.30$ & $0.20 \pm 0.10$ & $0.80 \pm 0.10$ & $0.97 \pm 0.05$ \\
Nov & $9.70 \pm 2.30$ & $0.70 \pm 0.20$ & $0.80 \pm 0.10$ & $0.98 \pm 0.05$ \\
Dec & $6.80 \pm 1.90$ & $1.00 \pm 0.30$ & $0.90 \pm 0.10$ & $1.05 \pm 0.05$ \\
\hline
\end{tabular}

23329

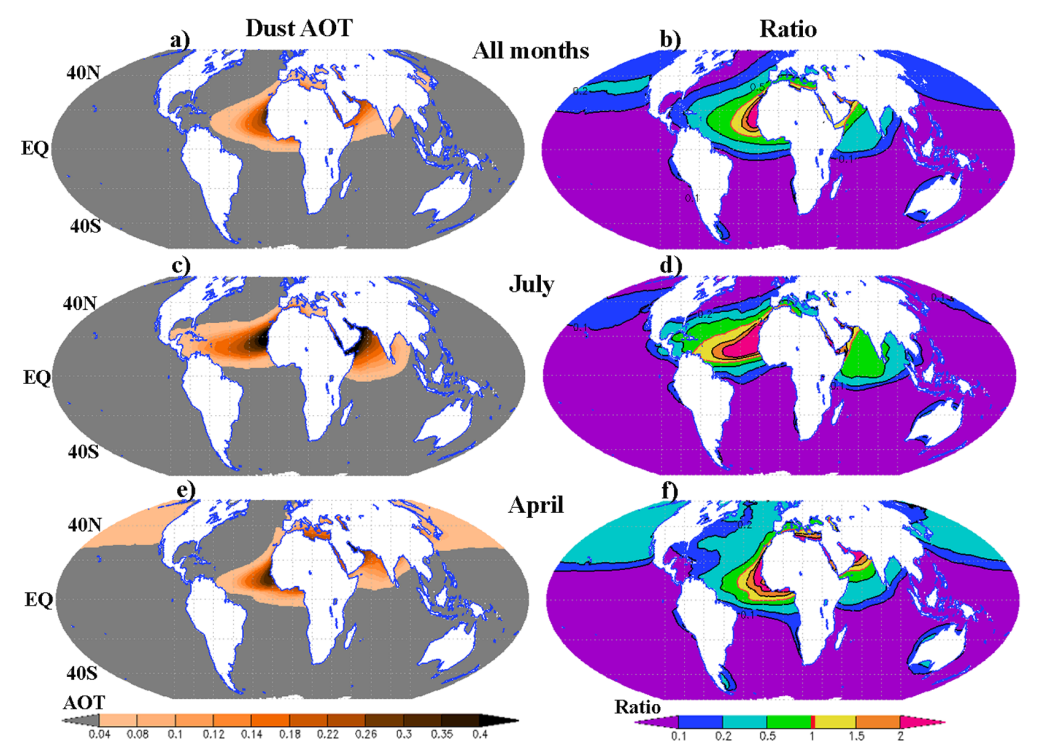

Figure 1. Spatial distributions of (a, $\mathbf{c}$ and $\mathbf{e})$ dust AOT (DU) and (b, $\mathbf{d}$ and $\mathbf{f})$ the ratio of DU to AOT of all other aerosol species, based on the $10 \mathrm{yr}$ MERRAero data. In the right panel, the red contour line represents the boundary of the zone where dust AOT is equal to AOT of all other aerosol species. 


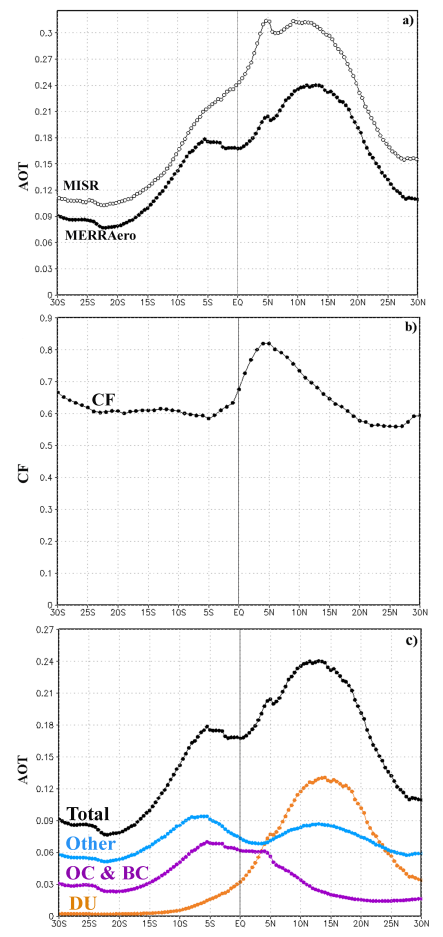

Figure 2. The meridional distribution of $10 \mathrm{yr}$ mean $A O T / C F$, zonal averaged over the Atlantic Ocean $\left(60^{\circ} \mathrm{W}-0^{\circ} \mathrm{E}\right)$ : (a) total AOT based on MERRAero and MISR data; (b) MODIS CF, (c) MERRAero total AOT, dust AOT (DU), organic and black carbon AOT (OC and BC), and other aerosol species AOT (Other). The vertical lines designate the position of the equator.

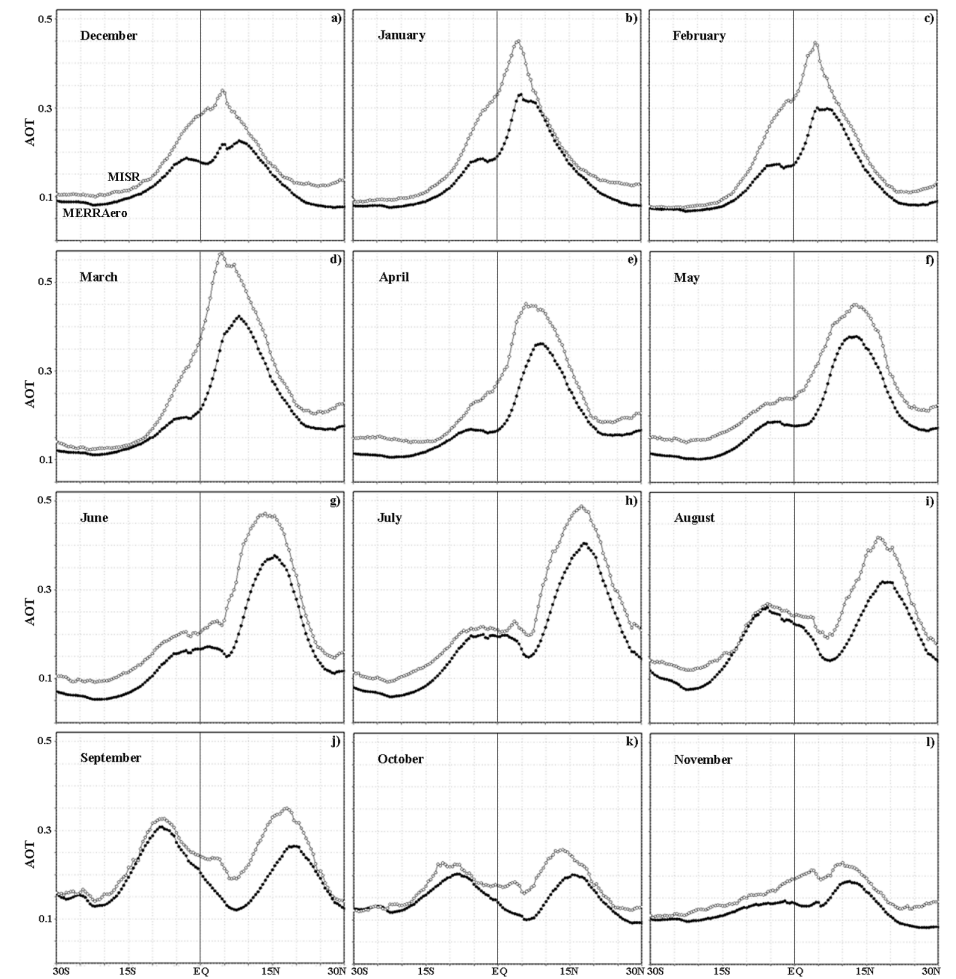

Figure 3. Meridional distribution of MISR and MERRAero total AOT, zonal averaged over the Atlantic Ocean, for all months of the year. The vertical lines designate the position of the equator. 


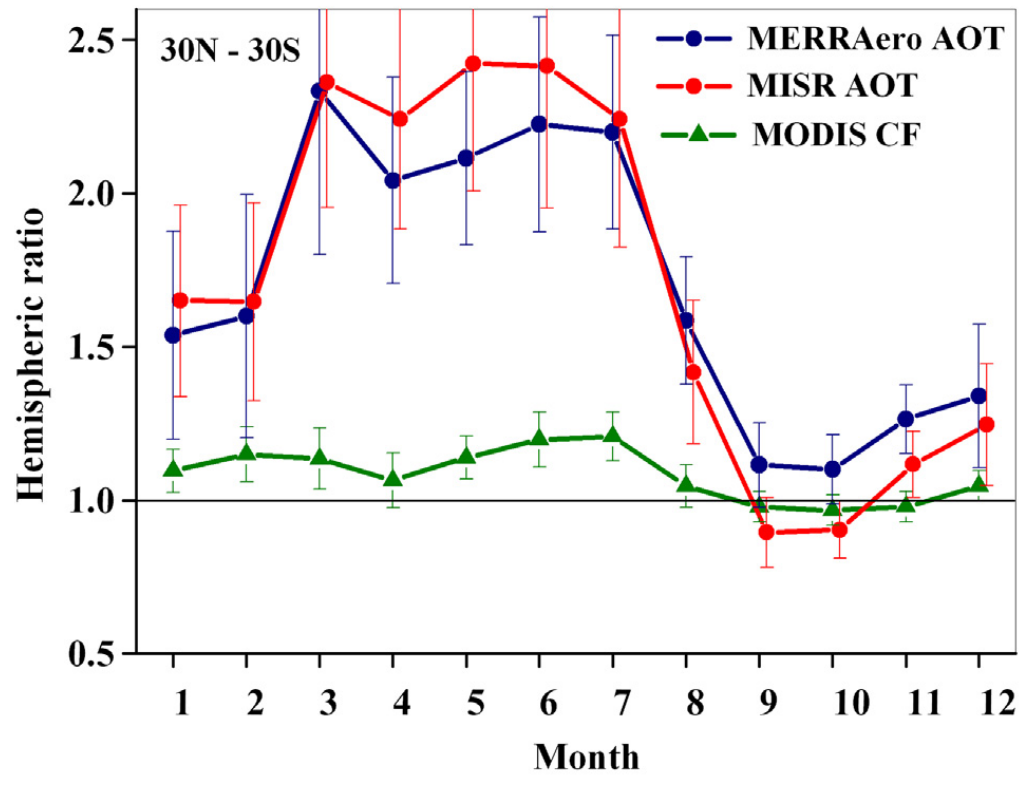

Figure 4. Month-to-month variations of the hemispheric ratio $(R)$ of MISR AOT, MERRAero AOT and MODIS cloud fraction (CF) over the tropical Atlantic Ocean $\left(30^{\circ} \mathrm{N}-30^{\circ} \mathrm{S}\right)$. The error bars show the standard deviation of $R$.

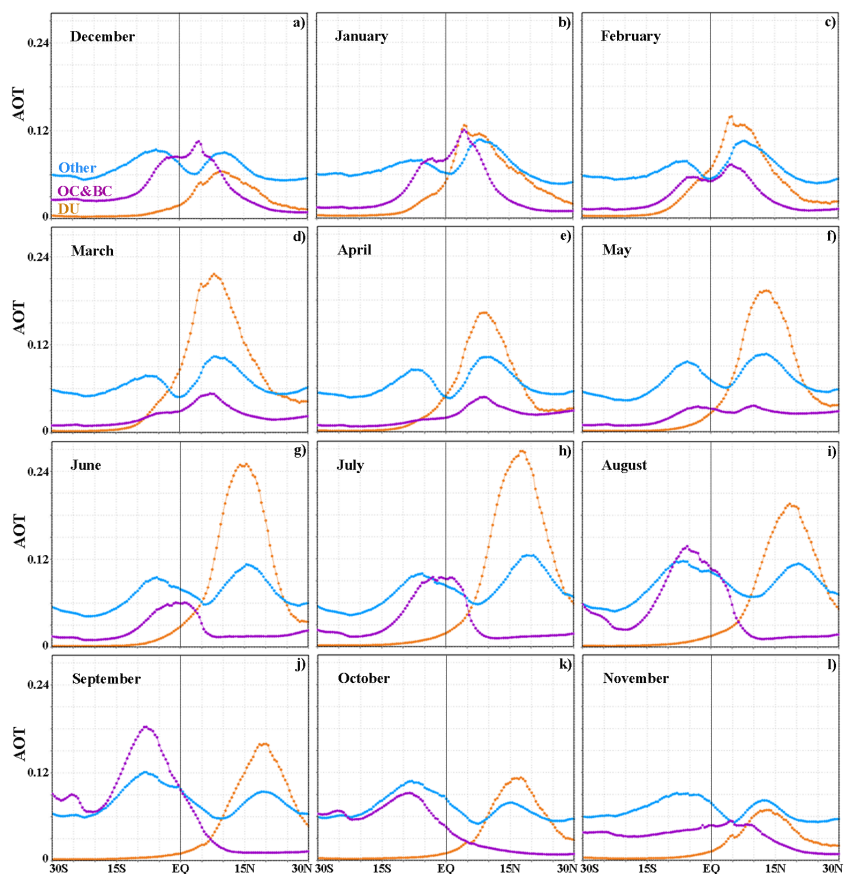

Figure 5. Meridional distribution of dust AOT (DU), organic and black carbon aerosol AOT (OC and $\mathrm{BC}$ ), and other aerosol species AOT (Other), zonal averaged over the Atlantic Ocean, for all months of the year, based on $10 \mathrm{yr}$ MERRAero data. The vertical lines designate the position of the equator. 


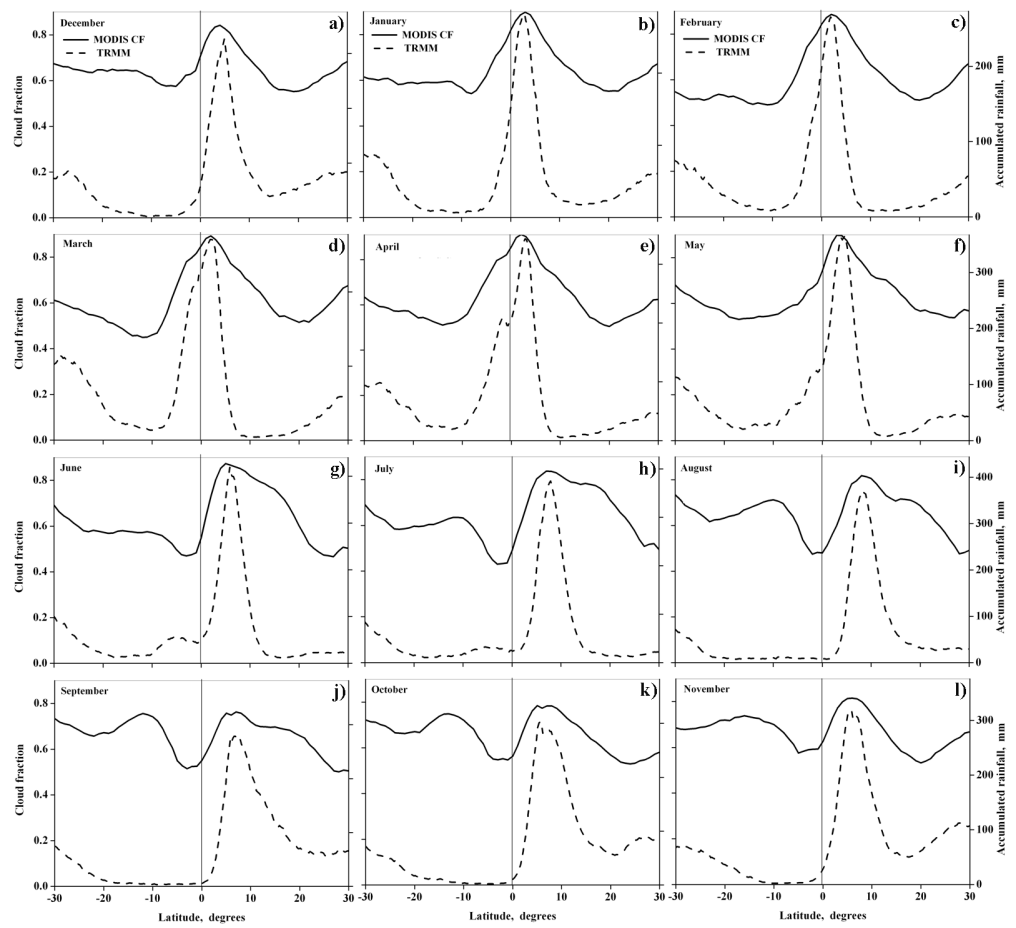

Figure 6. Meridional distribution of MODIS-Terra CF and TRMM accumulated rainfall, zonal averaged over the tropical Atlantic Ocean, for all months of the year. The vertical lines designate the position of the equator.

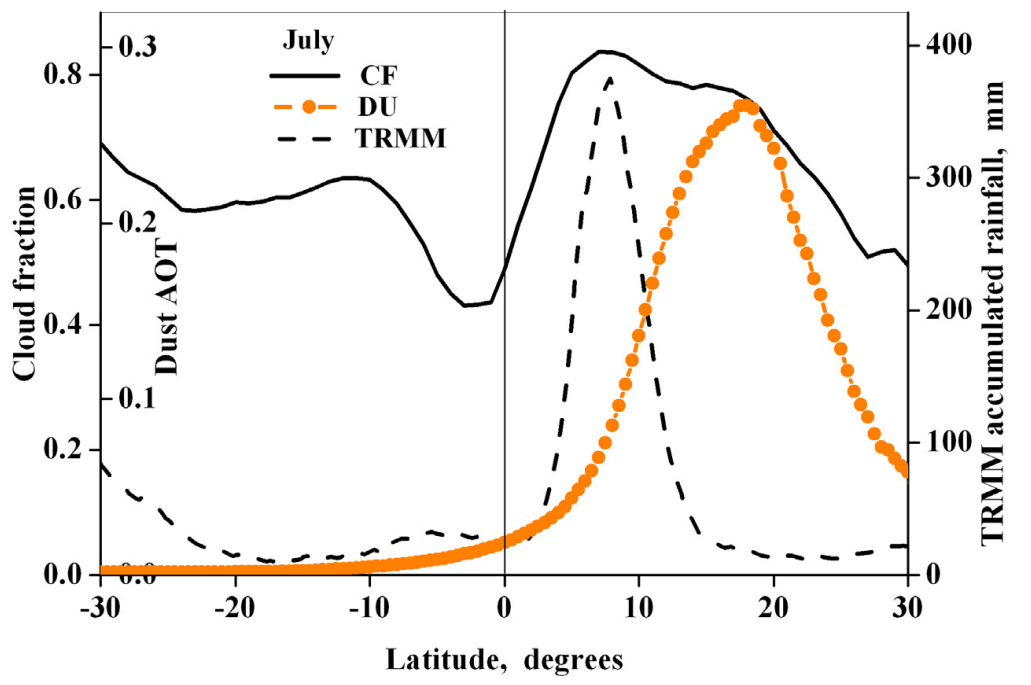

Figure 7. Meridional distribution of $10 \mathrm{yr}$ mean MODIS-Terra cloud fraction (CF), TRMM accumulated rainfall and MERRAero dust AOT (DU), zonal averaged over the Atlantic Ocean $\left(60^{\circ} \mathrm{W}-0^{\circ} \mathrm{E}\right)$, in July. The near-equatorial maximum in meridional distribution of TRMM accumulated rainfall indicates the position of the North Atlantic Ocean inter-tropical convergence zone (ITCZ). The vertical line designates the position of the equator. 

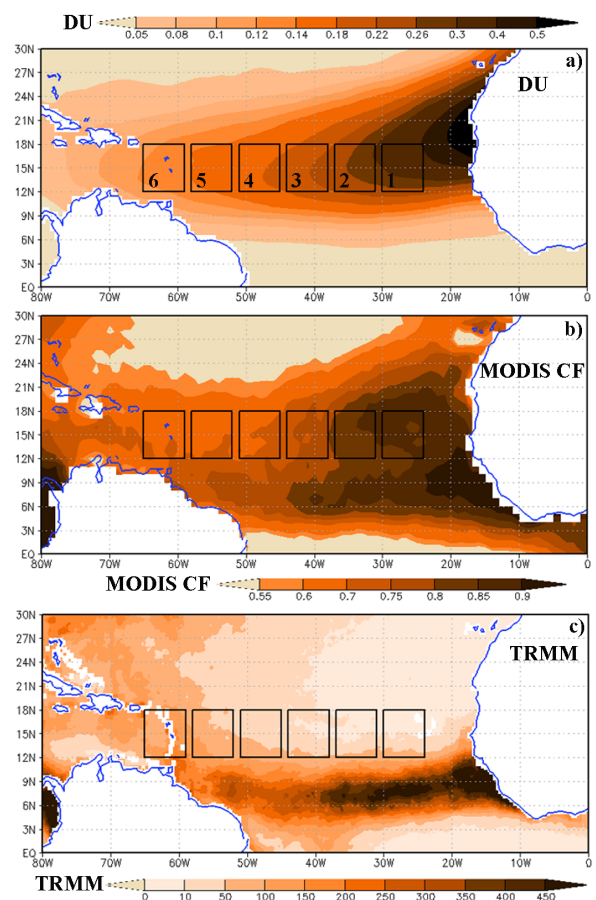

Figure 8. Spatial distributions of $10 \mathrm{yr}$ mean (a) MERRAero dust AOT (DU), (b) MODIS-Terra $\mathrm{CF}$, and (c) TRMM accumulated rainfall over the North Atlantic in July. The geographic coordinates of the specified zones are as follows: zone $1\left(12^{\circ} \mathrm{N}-18^{\circ} \mathrm{N} ; 30^{\circ} \mathrm{W}-24^{\circ} \mathrm{W}\right)$, zone $2\left(12^{\circ} \mathrm{N}-\right.$ $\left.18^{\circ} \mathrm{N} ; 37^{\circ} \mathrm{W}-31^{\circ} \mathrm{W}\right)$, zone $3\left(12^{\circ} \mathrm{N}-18^{\circ} \mathrm{N} ; 44^{\circ} \mathrm{W}-38^{\circ} \mathrm{W}\right)$, zone $4\left(12^{\circ} \mathrm{N}-18^{\circ} \mathrm{N} ; 51^{\circ} \mathrm{W}-45^{\circ} \mathrm{W}\right)$, zone $5\left(12^{\circ} \mathrm{N}-18^{\circ} \mathrm{N} ; 58^{\circ} \mathrm{W}-52^{\circ} \mathrm{W}\right)$, zone $6\left(12^{\circ} \mathrm{N}-18^{\circ} \mathrm{N} ; 65^{\circ} \mathrm{W}-59^{\circ} \mathrm{W}\right)$.

23337
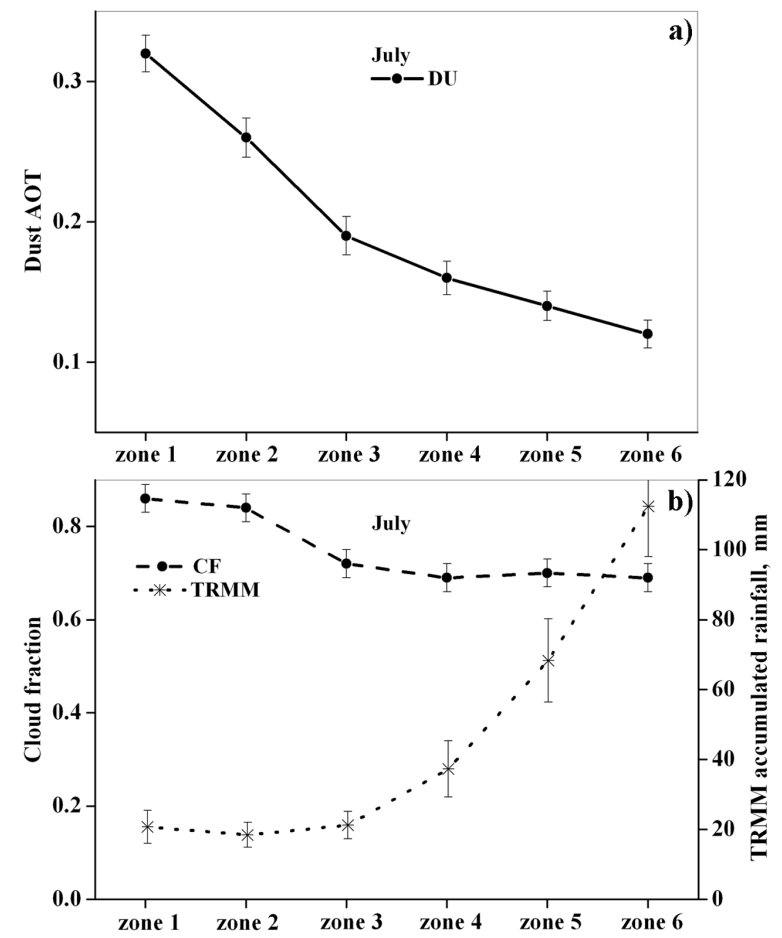

Figure 9. Zone-to-zone variations of (a) MERRAero dust AOT (DU); (b) MODIS-Terra CF and TRMM accumulated rainfall over the specified zones in July, averaged over the ten yr study period (2002-2012). The error bars show the standard error of mean. 


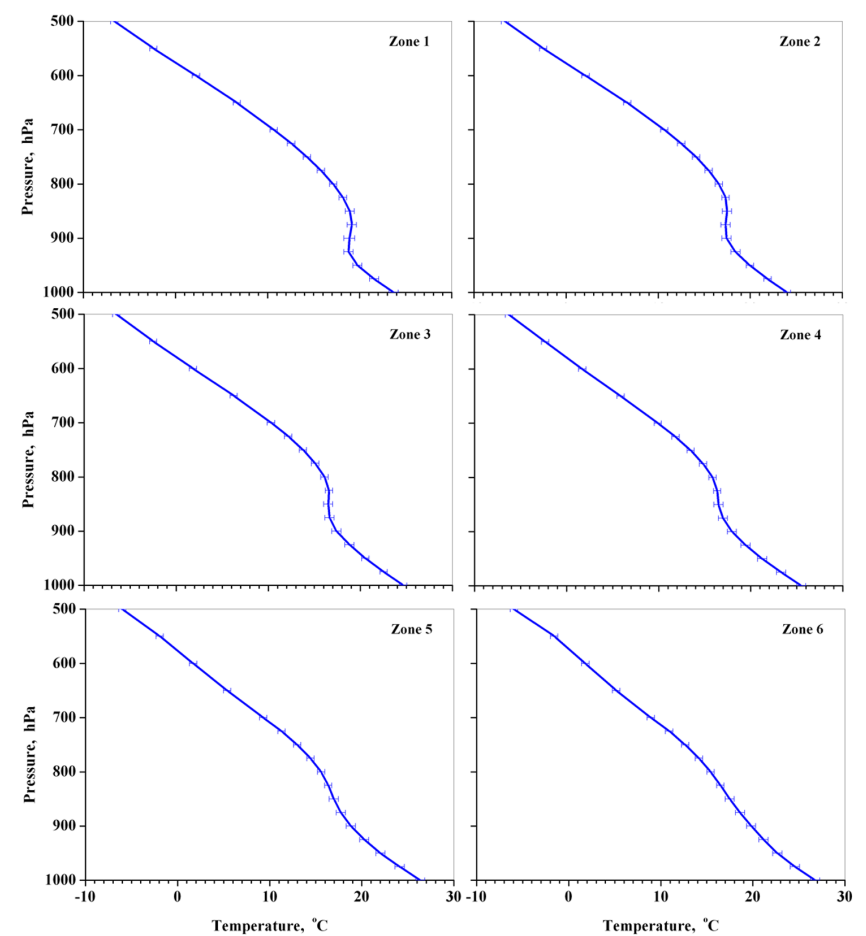

Figure 10. Vertical profiles of $10 \mathrm{yr}$ mean MERRA atmospheric temperature $\left({ }^{\circ} \mathrm{C}\right)$ in July, averaged over the specified zones along the route of transatlantic dust transport. The error bars show the standard deviation of temperature. 